GRASAS Y ACEITES 72 (3)

July-September 2021, e425

ISSN-L: 0017-3495

https://doi.org/10.3989/gya.0335201

\title{
Changes in fatty acid profile of Holothuria forskali muscle following acute mercury exposure
}

\author{
๑I. Rabeh ${ }^{\mathrm{a}, \bowtie}, \oplus \mathrm{K}$. Telahigue ${ }^{\mathrm{a}}, \oplus \mathrm{T}$. Hajji ${ }^{\mathrm{b}}, \oplus \mathrm{C}$. Fouzai ${ }^{\mathrm{a}}, \oplus \mathrm{M}$. El Cafsi ${ }^{\mathrm{a}}$ and $₫ N$. Soudani ${ }^{\mathrm{a}}$ \\ aLaboratory of Ecology, Biology and Physiology of Aquatic organisms, Faculty of Sciences of Tunis, Univ. Tunis El Manar, 2092 Tunis, Tunisia. \\ ${ }^{b}$ BVBGR-LR11ES31, Higher Institute of Biotechnology - Sidi Thabet, Biotechpole Sidi Thabet, Univ. Manouba, 2020 Ariana, Tunisia. \\ ${ }^{\otimes}$ Corresponding author: rabehimen@yahoo.fr
}

Submitted: 30 March 2020; Accepted: 10 August 2020; Published online: 21 September 2021

\begin{abstract}
SUMMARY: The present study aimed to document the interaction between mercury ( $\mathrm{Hg}$ ), as a model chemical stressor to an aquatic organism, and Fatty acid (FA) profile in the longitudinal muscle of the sea cucumber Holothuria forskali. To assess the sensitivity of this species to the toxic effects of $\mathrm{Hg}$, young $\mathrm{H}$. forskali were exposed to gradual doses of $\mathrm{Hg}\left(40,80\right.$ and160 $\left.\mu \mathrm{g} \cdot \mathrm{L}^{-1}\right)$ for $96 \mathrm{~h}$. The results showed that following $\mathrm{Hg}$ exposure, the FA profile of $H$. forskali corresponded to an increase in the level of saturated fatty acids, and the decrease in the level of monounsaturated and polyunsaturated fatty acids. The most prominent changes in the FA composition were recorded at the lowest dose with noticeable decreases in linoleic, arachidonic and eicosapentaenoic acid levels and an increase of docosahexaenoic acid. The occurrence of a state of oxidative stress induced by $\mathrm{Hg}$ contamination was evidenced by the enhanced levels of malondialdehyde, hydrogen peroxide and lipid hydroperoxide. Overall, the low concentration of mercury exerted the most obvious effects on lipid metabolism, suggesting that changes in fatty acid composition may be act as an early biomarker to assess mercury toxicity in this ecologically and economically important species.
\end{abstract}

KEYWORDS: Acute exposure; Fatty acid composition; Holothuria forskali; Indices of lipid peroxidation; Mercuric chloride $\left(\mathrm{HgCl}_{2}\right) ; \mathrm{Sea}$ cucumber

RESUMEN: Cambios en el perfil de ácidos grasos del músculo de Holothuria forskali tras una exposición aguda a mercurio. El presente estudio tuvo como objetivo demostrar la interacción entre el mercurio (Hg), como modelo de estresor químico para el organismo acuático, y el perfil de ácidos grasos (FA) en el músculo longitudinal del pepino de mar Holothuria forskali. Para evaluar la sensibilidad de esta especie a los efectos tóxicos del $\mathrm{Hg}$, los juveniles de $\mathrm{H}$. forskali fueron expuestos a dosis graduales de $\mathrm{Hg}\left(40,80 \mathrm{y} 160 \mu \mathrm{g} \cdot \mathrm{L}^{-1}\right)$ durante $96 \mathrm{~h}$. Los resultados mostraron que después de la exposición al Hg, el perfil de FA de H. forskali respondió con una tendencia direccional anclada por el aumento en el nivel de ácidos grasos saturados y la disminución en el nivel de ácidos grasos monoinsaturados y poliinsaturados. Los cambios más prominentes en la composición de AG se registraron a la dosis más baja con una disminución notable en los niveles de ácido linoleico, araquidónico y eicosapentaenoico frente a un aumento de ácido docosahexaenoico. La aparición de un estado de estrés oxidativo inducido por la contaminación con $\mathrm{Hg}$ se puso de manifiesto por el aumento en los niveles de malondialdehído, peróxido de hidrógeno e hidroperóxido de lípidos. En general, la concentración más baja de mercurio ejerció efectos más obvios sobre el metabolismo de los lípidos, lo que sugiere que los cambios en la composición de los ácidos grasos pueden actuar como un biomarcador anterior para evaluar la toxicidad del mercurio en esta especie de importancia ecológica y económica.

PALABRAS CLAVE: Cloruro de mercurio ( $\left.\mathrm{HgCl}_{2}\right)$; Composición de ácidos grasos; Exposición aguda; Holothuria forskali; Índices de peroxidación lipídica; Pepino de mar

Citation/Cómo citar este artículo: Rabeh I, Telahigue K, Hajji T, Fouzai C, El Cafsi M, Soudani N. 2021. Changes in fatty acid profile of Holothuria forskali muscle following acute mercury exposure. Grasas Aceites 72 (3), e425. https://doi.org/10.3989/gya.0335201

Copyright: (C2021 CSIC. This is an open-access article distributed under the terms of the Creative Commons Attribution 4.0 International (CC BY 4.0) License. 


\section{INTRODUCTION}

Over the last centuries, the environmental impacts of heavy metal pollution have increased in the coastal areas, causing a major threat to the ecosystems and the biota they support (Ruiz et al., 2014). Among these xenobiotics, mercury $(\mathrm{Hg})$ is listed as one of the most toxic elements due to its tendency to bioaccumulate and biomagnify through the food chain (Balshaw et al., 2007). The sources of mercury contamination in aquatic ecosystems include natural and anthropogenic emissions (Verlecar et al., 2008). The later generally come from incineration, fungicides, paints and industrial processes. One of the established mechanisms of $\mathrm{Hg}$ toxicity is its ability to induce cellular oxidative stress through the generation of reactive oxygen species (ROS) which react with macromolecules such as lipids, proteins and DNA (Uttara et al., 2009). As the cell membrane is tightly linked to cellular physiology, several authors have reported that the membrane is the primary detector of stress stimuli and activator of the cellular stress response (Dindia et al., 2013; Vígh et al., 2007). According to several authors, changes in the membrane biophysical properties as a primary response to stress, mainly trigger changes in lipid and fatty acid compositions (Los et al., 2004; Thyrring et al., 2015). Indeed, FAs, as the main constituent of the cell membrane, play crucial roles in several physiological functions as well as in the maintenance of membrane structures (Neves et al., 2015). It therefore appears that lipids and their constitutional components could be closely involved in cellular responses to pollutants such as $\mathrm{Hg}$ in aquatic organisms (Ferrain et al., 2018). In this context, it has been proven that the susceptibility of individual FA to peroxidation increases exponentially with an increasing number of double bonds on the carbon chain (Holman, 1954). Thus, polyunsaturated fatty acids (PUFAs) like eicosapentaenoic acid (20:5n-3, EPA) and docosahexaenoic acid (22:6n-3, DHA) are not only targets that are damaged by ROS, but also play a key role in enhancing an organism's adaptation to environmental stress (Munro et al., 2016). Given this, FAs were recently argued to be promising bioindicators to assess stress exposure and ecosystem health in a marine environment (Silva et al., 2017).

Nowadays, most of the available data regarding the use of FA as biomarkers for marine pollution monitoring refers to bivalves, micro and macroalgae and fish (Filimonova et al., 2016; Gonçalves et al., 2016); however, little is known about other marine organisms such as holothurians. Our previous study (Telahigue et al., 2019) investigated for the first time, the impact of acute mercury exposure on several biochemical parameters including fatty acid profile in the Holothuria forskali body wall. Holothurians, commonly known as sea cucumbers, represent an important marine resource due to their numerous nutraceutical and pharmaceutical proprieties (Bordbar et al., 2011). The sea cucumber fishery and aquaculture trade have been an active industry in Asia for a long time. In recent years, the sea cucumber trade has also flourished in some Mediterranean sea and NE Atlantic Ocean countries (Sicuro and Levine, 2011). The black sea cucumber or cotton-spinner Holothuria forskali, which is one of the most common sea cucumber species in the Mediterranean sea, is listed as a new target resource for future farming industries. (Sicuro and Levine, 2011). Like most of other sea cucumbers species, $H$. forskali is a deposit feeder and may ingest a large amount of sediment (Navarro et al., 2014) which make it particularly prone to heavy metal pollution. Several authors have reported that sea cucumbers could be considered as a potential bioindicator for heavy metal pollution (Turk Culha et al., 2016). Indeed, it is well established that mercury tends to accumulates in tissue in a specific manner depending on the organ's physiological role and its regulatory ability. Generally, some tissues/organs such as body wall and respiratory tree have received particular attention to evaluate the impact of noxious stimuli in holothurians. Nonetheless, little information is available on the longitudinal muscles. In fact, muscle constitutes an interesting organ to analyze owing to the energy supply function and to its major role in locomotion and contraction movements in response to environmental stimuli and to its being a target tissue for bioaccumulation of merury (as confirmed by unpublished data obtained in our laboratory). The current study was mainly designed to evaluate the impact of $\mathrm{Hg}$ contamination on the fatty acid composition of $H$. forskali muscle. The results may provide valuable data concerning the underlying toxicity mechanism of $\mathrm{Hg}$ in lipid metabolism and to verify the validity of the FA profile as a biomarker of mercury intoxication in sea cucumber. Other 
parameters such as levels of $\mathrm{H}_{2} \mathrm{O}_{2}$ and $\mathrm{LOOH}$ were also assessed in order to verify the induction of an oxidative stress state in $H$. forskali muscle tissue following acute $\mathrm{Hg}$ exposure.

\section{MATERIALS AND METHODS}

\subsection{Chemicals}

Mercury chloride $\left(\mathrm{HgCl}_{2}>99.5 \%\right.$ purity $)$ was obtained from Sigma-Aldrich (St. Louis, MO, USA). It was dissolved in pure water for stock concentrations, and the desired test solutions used in the present study were prepared by diluting the stock solution with double-distilled water. Reduced glutathione (GSH), 5,5-dithiobis-2-nitrobenzoic acid (DTNB), and thiobarbituric acid (TBA) were purchased from Sigma Chemical Co. (St. Louis, MO, USA). All other chemicals were purchased from standard commercial suppliers.

\subsection{Experimental design}

Young $H$. forskali, with an average body length of $20.25 \pm 2.75 \mathrm{~cm}$, were collected by hand during scuba diving off the Bizerte coast (North east of Tunisia), a relatively clean sea shore. The sea cucumbers were transported to the laboratory in cooler boxes with water from the collection site. Once in the laboratory, the specimens were kept in tanks filled with aerated seawater $\left(18{ }^{\circ} \mathrm{C} \pm 1\right.$; photoperiod of $\left.12: 12 \mathrm{~h}\right)$ for three days prior to experimentation. The animals were acclimated and then randomly divided into 4 groups of 12 specimens each (triplicate design) in order to ensure the reproducibility of the results. As we proceeded in our previously published research (Rabeh et al., 2018), the animals were exposed to a range of mercury chloride $\left(\mathrm{HgCl}_{2}\right)$ concentrations as follows: (controls $(0), \mathrm{D} 1\left(40 \mu \mathrm{g} \cdot \mathrm{L}^{-1}\right), \mathrm{D} 2\left(80 \mu \mathrm{g} \cdot \mathrm{L}^{-}\right.$ $\left.{ }^{1}\right)$ and D3 $\left(160 \mu \mathrm{g} \cdot \mathrm{L}^{-1}\right)$. Tested doses were chosen based on studies that investigated the effects of the acute exposure of marine invertebrates to mercury, using similar concentrations (Bhamre et al., 2010; Oliveira et al., 2015). The lowest concentration $\left(40 \mu \mathrm{g} \cdot \mathrm{L}^{-1}\right)$ was in the range of concentrations that can be found in some heavily contaminated water bodies near industrialized areas (Alinnor, 2005; Guilherme et al., 2008); while the highest tested concentrations (60 and $\left.80 \mu \mathrm{g} \cdot \mathrm{L}^{-1}\right)$, were selected to guarantee the observable effects of $\mathrm{Hg}$ and to elucidate the responsiveness of sea cucumber to the worst-case-scenario of mercury contamination. To ensure water quality, $50 \%$ of the water was replaced every $24 \mathrm{~h}$ and the concentrations of mercuric chloride were re-established. The changed volume of water was replaced by an equal amount of water containing the initial concentration of $\mathrm{HgCl}_{2}$. During the exposure period, sea cucumbers were not fed to avoid prandial effects and to prevent the deposition of feces. No mortalities were observed throughout the experimental period in any group. At the end of experiments, nine animals from each treatment were removed from the tanks by dip-net and weighed. Muscle was carefully dissected and immediately frozen in liquid nitrogen and then stored at $-80^{\circ} \mathrm{C}$ until the biochemical assays were carried out.

\subsection{Hydrogen peroxide generation assay}

The amount of hydrogen peroxide $\left(\mathrm{H}_{2} \mathrm{O}_{2}\right)$ generation in tissues was monitored by the ferrous ion oxidation xylenol orange method of $\mathrm{Ou}$ and Wolff (1996). The amount of $\mathrm{H}_{2} \mathrm{O}_{2}$ produced was determined using the extinction coefficient of $2.67 \times 105 \mathrm{~cm}^{-1} \mathrm{M}^{-1}$ and results were expressed as nmol per gram of tissue.

\subsection{Lipid hydroperoxide assay}

Lipid hydroperoxide levels were estimated using the ferrous oxidation in xylenol orange assay (FOX assay) described by Jiang et al., (1992). The amount of hydroperoxides produced was calculated using the molar extinction coefficient of $4.6 \times 9 \times 104 \mathrm{M}^{-1}$ $\mathrm{cm}^{-1}$, and the results were expressed as nanomoles per milligram of protein.

\subsection{Lipid extraction}

Total lipids in each sample were extracted according to the Folch, Lees, and Sloane-Stanley (1957) method with the solvent mixture chloroformmethanol $(2: 1, v / v)$. Following solvent evaporation under nitrogen, lipids were transferred to preweighed $2 \mathrm{ml}$ vials. The solvent mixture was again evaporated under nitrogen, and the extracts were further dried overnight at ambient temperature (18 ${ }^{\circ} \mathrm{C}$ ) in a vacuum desiccator. Once weighed, the lipids were re-dissolved in chloroform-methanol (2:1, $\mathrm{v} / \mathrm{v}$ ) with $0.01 \%$ butylated hydroxy toluene (BHT, Sigma-Aldrich) added as an antioxidant to minimize the risk of lipid oxidation. 


\subsection{Fatty acid analysis}

Fatty acids from total lipid extracts were transesterified according to the Cecchi et al., (1985) method. Methyl nonadecanoate C19:0 (Sigma) was added as internal standard. The resulting fatty acid methyl esters (FAME) were extracted using sodium methylate $\left(\mathrm{NaOCH}_{3}\right)$ in the presence of hexane and sulfuric acid $\left(\mathrm{H}_{2} \mathrm{SO}_{4}\right)$. Separation of FAMEs was carried out on a HP 6890 gas chromatograph (Agilent Technologies, Sacramento,CA, USA) with a split/splitless injector equipped with a flame ionization detector at $275^{\circ} \mathrm{C}$, and a $30 \mathrm{~m} \mathrm{HP}$. Innowax capillary column with an internal diameter of $250 \mu \mathrm{m}$ and a $0.25 \mu \mathrm{m}$ film thickness. The injector temperature was held at $250{ }^{\circ} \mathrm{C}$. The oven was programmed to rise from 50 to $180^{\circ} \mathrm{C}$ at a rate of $4{ }^{\circ} \mathrm{C} \cdot \mathrm{min}^{-1}$, from 180 to $220^{\circ} \mathrm{C}$ at $1.33^{\circ} \mathrm{C} \cdot \mathrm{min}^{-1}$ and to stabilize at $220^{\circ} \mathrm{C}$ for $7 \mathrm{~min}$. The carrier gas was nitrogen. Identification of FAMEs was based on the comparison of their retention times with those of a mixture of methyl esters (Supelco 47085U PUFA No: 3 and Supelco 37 component FAME mix 47885U). Fatty acid peaks were integrated and analyzed using Hewlett-Packard ChemStation software. All fatty acid data are reported as percentage of total fatty acids.

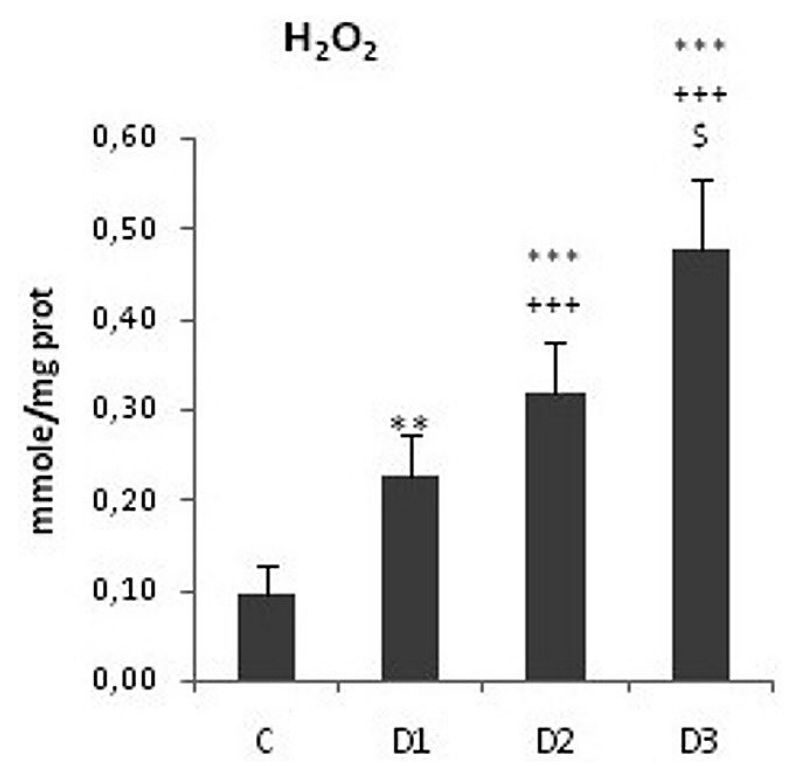

\subsection{Calculation of indices and statistical analysis}

The indices of desaturase activities were estimated as the product/precursor ratios of individual fatty acids according to the following formulas:

D9D: $\Delta 9$-desaturase $=$ stearoyl-CoA-desaturase $=$ $(C 18: 1 n-9) / C 18: 0)$; D5D: $\Delta 5$-desaturase $=C 20: 5 \mathrm{n} 3 /$ C20:4n3, D6D: $\Delta 6$-desaturase $=22: 6 n-3 /$ C20:5n-3 (Da costa et al., 2015; Rabei et al., 2018).

The indices of the elongase (Elovl 6) activity were calculated using the $\mathrm{C} 18: 0 / \mathrm{C} 16: 0$ ratio (Kotronen et al., 2010).

Mercuric chloride effects on fatty acid composition were analyzed by one way ANOVA of variance (ANOVA) followed by the Tukey's test in order to compare results between doses. Results were expressed as mean $\pm \mathrm{SD}$ and differences were considered significant at $p<0.05$. First the data for each variable was checked for normality and homogeneity of variance by Kolmogorov-Smirnov and Levene's tests, respectively. Raw values were arcsine-transformed or $\log _{10}$-transformed (if necessary) to meet the requirements for normal distribution and homogeneity of the variances. Student unpaired t-test was also used when comparison between two groups was required. All statistical analyses were run by the statistical software program R version 3.0.2 (R Core Team2017).



FiguRE 1. Levels of oxidative damage measured as hydrogen peroxide generation $\left(\mathrm{H}_{2} \mathrm{O}_{2}\right)$ and in the muscle of unexposed (C) and exposed Holothuria forskali to different doses of $\mathrm{HgCl}_{2}$ for $96 \mathrm{~h}$. Data were expressed as means $\pm \mathrm{SD}(\mathrm{n}=9)$. ${ }^{*} \mathrm{p}<0.01 ; * * \mathrm{p}<0.001$ : D1, D2 and D3 groups vs. control group. $+p<0.01 ;++p<0.001$ : D2 and D3 groups vs. D1 group. $\$ p<0.001$ : D3 group vs. D2 group 
TABLE1. Fatty acid profile (\%) of Holothuria forskali muscle of the control and $\mathrm{HgCl}_{2}$-treated groups (D1 (40 $\left.\mu \mathrm{g} \cdot \mathrm{L}^{-1}\right), \mathrm{D} 2\left(80 \mu \mathrm{g} \cdot \mathrm{L}^{-1}\right)$ and D3 $\left.\left(160 \mu \mathrm{g} \cdot \mathrm{L}^{-1}\right)\right)$ for 4 days.

\begin{tabular}{|c|c|c|c|c|}
\hline Fatty acids & Control & Hg (D1) & $\mathrm{Hg}$ (D2) & Hg (D3) \\
\hline $\mathrm{C} 14: 0$ & $5.46 \pm 0.4^{\mathrm{a}}$ & $3.61 \pm 0.05^{\mathrm{b}}$ & $4.93 \pm 0.86^{\mathrm{d}}$ & $4.61 \pm 0.51^{\mathrm{c}}$ \\
\hline C15:0 & $1.15 \pm 0.15^{\mathrm{a}}$ & $4.77 \pm 0.22^{b}$ & $3.93 \pm 0.01^{\mathrm{c}}$ & $2.08 \pm 0.20^{\mathrm{b}}$ \\
\hline $\mathrm{C} 14: 1$ & $0.22 \pm 0.23^{\mathrm{a}}$ & $0.52 \pm 0.08^{b}$ & $1.00 \pm 0.50^{\mathrm{c}}$ & $1.31 \pm 0.35^{\mathrm{c}}$ \\
\hline C15:1 & $1.40 \pm 0.14^{\mathrm{a}}$ & $5.75 \pm 0.12^{b}$ & $1.87 \pm 0.08^{\mathrm{a}}$ & $0.88 \pm 0.54^{\mathfrak{c}}$ \\
\hline $\mathrm{C} 16: 0$ & $4.86 \pm 1.4^{\mathrm{a}}$ & $9.74 \pm 0.34^{b}$ & $5.35 \pm 0.75^{\mathrm{c}}$ & $5.02 \pm 0.13^{c}$ \\
\hline C16:1n-9 & $4.37 \pm 0.17^{\mathrm{a}}$ & $3.67 \pm 0.17^{\mathrm{b}}$ & $3.74 \pm 1.63^{\mathrm{a}}$ & $7.29 \pm 1.32^{b}$ \\
\hline $\mathrm{C} 16: 1 \mathrm{n}-7$ & $8.72 \pm 1.42^{\mathrm{a}}$ & $3.97 \pm 0.29^{b}$ & $8.60 \pm 0.32^{\mathrm{a}}$ & $4.83 \pm 1.16^{\mathrm{c}}$ \\
\hline C16:2n-4 & $2.42 \pm 0.13^{\mathrm{a}}$ & $1.50 \pm 0.05^{\mathrm{b}}$ & $2.89 \pm 0.28^{\mathrm{c}}$ & $1.82 \pm 0.31^{\mathrm{a}}$ \\
\hline $\mathrm{C} 17: 0$ & $0.4 \pm 0.15^{\mathrm{a}}$ & $1.56 \pm 0.27^{\mathrm{b}}$ & $1.20 \pm 0.08^{b}$ & $2.70 \pm 0.44^{\mathrm{c}}$ \\
\hline $\mathrm{C} 16: 4$ & $2.81 \pm 0.30^{\mathrm{a}}$ & $1.78 \pm 0.36^{\mathrm{b}}$ & $1.51 \pm 0.05^{\mathrm{b}}$ & $2.46 \pm 0.15^{\mathrm{a}}$ \\
\hline$C 16: 3 n-4$ & $3.35 \pm 0.5^{\mathrm{a}}$ & $6.37 \pm 0.80^{\mathrm{b}}$ & $2.25 \pm 0.30^{\mathrm{b}}$ & $2.24 \pm 0.26^{\mathrm{b}}$ \\
\hline C18:0 & $5.62 \pm 0.49^{\mathrm{a}}$ & $6.83 \pm 0.13^{\mathrm{b}}$ & $5.12 \pm 1.06^{\mathrm{c}}$ & $4.55 \pm 0.52^{\mathrm{c}}$ \\
\hline C18:1n-9 & $2.38 \pm 0.01^{\mathrm{a}}$ & $1,15 \pm 0.10^{\mathrm{b}}$ & $1.06 \pm 0.03^{b}$ & $2.04 \pm 0.25^{\mathrm{c}}$ \\
\hline C18:1n-7 & $1.92 \pm 0.2^{\mathrm{a}}$ & $0.62 \pm 0.18^{b}$ & $1.36 \pm 0.09^{c}$ & $2.46 \pm 0.57^{\mathrm{d}}$ \\
\hline C18:2n-6 & $11.6 \pm 1.23^{\mathrm{a}}$ & $4.42 \pm 0.65^{\mathrm{b}}$ & $11.48 \pm 0.40^{\mathrm{a}}$ & $13.79 \pm 1.90^{\mathrm{d}}$ \\
\hline C18:4n-3 & $2.05 \pm 0.29^{\mathrm{a}}$ & $6.93 \pm 0.51^{\mathrm{b}}$ & $4.25 \pm 0.08^{c}$ & $1.35 \pm 0.10^{\mathrm{a}}$ \\
\hline C18:3n-3 & $2.08 \pm 0.05^{\mathrm{a}}$ & $4.85 \pm 0.42^{\mathrm{b}}$ & $2.46 \pm 0.42^{\mathrm{a}}$ & $1.92 \pm 0.15^{\mathrm{c}}$ \\
\hline C20:0 & $3.73 \pm 0.45^{\mathrm{a}}$ & $3.19 \pm 0.40^{\mathrm{b}}$ & $4.19 \pm 0.06^{\mathrm{a}}$ & $2.60 \pm 0.28^{b}$ \\
\hline C20:1n-9 & $6.69 \pm 0.8^{\mathrm{a}}$ & $3.04 \pm 0.04^{\mathrm{b}}$ & $7.87 \pm 0.34^{\mathrm{a}}$ & $7.74 \pm 0.35^{c}$ \\
\hline$C 20: 3 n-6$ & $4.94 \pm 0.09^{\mathrm{a}}$ & $1.97 \pm 0.06^{\mathrm{b}}$ & $6.16 \pm 0.12^{\mathrm{a}}$ & $7.70 \pm 0.53^{c}$ \\
\hline$C 20: 2 n-6$ & $5.91 \pm 0.24^{\mathrm{a}}$ & $9.07 \pm 0.05^{b}$ & $5.87 \pm 0.13^{c}$ & $4.25 \pm 0.84^{\mathrm{d}}$ \\
\hline C20:4n-6 & $4.68 \pm 0.03^{\mathrm{a}}$ & $0.57 \pm 0.06^{\mathrm{b}}$ & $2.35 \pm 0.12^{\mathrm{c}}$ & $6.06 \pm 0.93^{d}$ \\
\hline$C 20: 3 n-3$ & $3.31 \pm 0.01^{\mathrm{a}}$ & $2.25 \pm 0.20^{\mathrm{b}}$ & $3.89 \pm 0.28^{\mathrm{a}}$ & $2.41 \pm 0.12^{\mathrm{c}}$ \\
\hline$C 20: 5 n-3$ & $3.13 \pm 0.43^{\mathrm{a}}$ & $1.30 \pm 0.06^{\mathrm{b}}$ & $1.27 \pm 0.11^{\mathrm{b}}$ & $3.17 \pm 0.41^{\mathrm{a}}$ \\
\hline $\mathrm{C} 22: 0$ & $0.38 \pm 0.08^{\mathrm{a}}$ & $1.01 \pm 0.07^{\mathrm{b}}$ & $0.62 \pm 0.05^{b}$ & $0.69 \pm 0.08^{b}$ \\
\hline $\mathrm{C} 22: 1$ & $0.36 \pm 0.02^{\mathrm{a}}$ & $0.11 \pm 0.01^{\mathrm{b}}$ & $0.16 \pm 0.04^{b}$ & $0.09 \pm 0.01^{\mathrm{b}}$ \\
\hline C22:5n-6 & $2.46 \pm 0.08^{\mathrm{a}}$ & $1.14 \pm 0,20^{\mathrm{b}}$ & $0.99 \pm 0.07^{\mathrm{b}}$ & $2.02 \pm 0.47^{\mathrm{a}}$ \\
\hline$C 22: 6 n-3$ & $3.62 \pm 0.02^{\mathrm{a}}$ & $7.05 \pm 1.18^{b}$ & $1.72 \pm 0.17^{\mathrm{c}}$ & $2.79 \pm 0.38^{\mathrm{a}}$ \\
\hline$\sum \mathrm{SFA}$ & $21.85 \pm 0.89^{\mathrm{a}}$ & $31.72 \pm 0.94^{\mathrm{b}}$ & $24.23 \pm 0.77^{\mathrm{a}}$ & $22.09 \pm 5.55^{\mathrm{c}}$ \\
\hline$\sum$ MUFA & $25.79 \pm 0.72^{\mathrm{a}}$ & $19.11 \pm 0.42^{\mathrm{b}}$ & $27.70 \pm 3.08^{a}$ & $27.02 \pm 5.90^{\mathrm{a}}$ \\
\hline$\sum$ PUFA & $52.36 \pm 3.26^{\mathrm{a}}$ & $49.17 \pm 1.38^{\mathrm{b}}$ & $48.07 \pm 3.03^{\mathrm{b}}$ & $51.15 \pm 11.45^{\mathrm{a}}$ \\
\hline$\sum$ PUFA (n-3) & $14.20 \pm 1.21^{\mathrm{a}}$ & $22.38 \pm 1.94^{\mathrm{b}}$ & $13.59 \pm 2.29^{\mathrm{a}}$ & $11.63 \pm 0.09^{\mathrm{c}}$ \\
\hline$\sum$ PUFA (n-6) & $23.67 \pm 1.20^{\mathrm{a}}$ & $13.57 \pm 0.3^{\mathrm{b}}$ & $26.85 \pm 0.24^{\mathrm{c}}$ & $34.15 \pm 13.08^{\mathrm{d}}$ \\
\hline$n-3 / n-6$ & $0.59 \pm 0.05^{\mathrm{a}}$ & $1.67 \pm 0.01^{\mathrm{b}}$ & $0.5 \pm 0.08^{\mathrm{a}}$ & $0.34 \pm 0.03^{c}$ \\
\hline Total lipid (mg/g ww) & $5.64 \pm 0.16^{\mathrm{a}}$ & $0.99 \pm 0.03^{b}$ & $7.5 \pm 0.41^{\mathrm{c}}$ & $10.19 \pm 1.02^{\mathrm{d}}$ \\
\hline
\end{tabular}

Data are expressed as percentage of major fatty acids (mean \pm standard deviation; $n=9$ ); Means followed by different letters in the same line are significantly different $(\mathrm{p}<0.05)$ by Tukey's test.

SFAs: saturated fatty acids, MUFAs: monounsaturated fatty acids, PUFAs: polyunsaturated fatty acids 
Principal Component Analysis (PCA) was applied to evaluate the relationship between mercury treatments and fatty acid composition in the muscle of the control and the exposed groups of $H$. forskali.

\section{RESULTS}

\subsection{Lipid hydroperoxide (LOOHs), and hydrogen peroxide $\left(\mathrm{H}_{2} \mathrm{O}_{2}\right)$ levels}

Significant increases $(p<0.05)$ in $\mathrm{H}_{2} \mathrm{O}_{2}$ and LOOH levels were recorded in the treated $H$. forskali, respectively, compared to the controls (Figure 1).

\subsection{Fatty acids composition}

As shown in Table 1, a significant decrease in lipid content was recorded in D1 however, in D2 and D3 a substantial increase was noticed compared to the control. The Fatty acid profiles of the muscle in the control and $\mathrm{HgCl}_{2}$-treated $\mathrm{H}$. forskali are presented in Table 1. The untreated sea cucumber group showed a significantly higher proportion of polyunsaturated fatty acids (PUFA) $(52.36 \%$ of total FA) followed by monounsaturated fatty acids (MUFA) and saturated fatty acids (SFA) with 25.79 and $21.84 \%$, respectively. Over all, we noticed that exposure to the nominal dose of $\mathrm{Hg}(\mathrm{D} 1,40 \mu \mathrm{g} \cdot \mathrm{L}-$ 1) substantially changed the main fatty acid groups. In fact, significant increases in SFA levels with a decrease in unsaturated fatty acid levels (MUFA and PUFA) were observed compared to the controls. A closer examination of data showed that the recorded increase in the SFA group, which almost doubled under D1 treatment, was mainly due to the increased levels of C15:0 and C16:0. As for unsaturated fatty acids, we recorded that $\mathrm{C} 18: 1 \mathrm{n}-7$ and $\mathrm{C} 20: 1 \mathrm{n}-9$ were the most affected FAs by the $\mathrm{Hg}$ treatments and to a lesser extent in D2 and D3. In the PUFA group, the primary source of variation was due to the decrease in the n-6 group level in D1. In fact, the levels of C18:2n-6 and C20:4n-6 dropped by 70 and $90 \%$, respectively, compared to the control group. Regarding the n-3 group, significant decreases of 70 and $40 \%$ were recorded for the EPA (C20: 5n3) levels in D1 and D2 groups, respectively. The EPA level remained statistically unchanged in the D3 group in comparison to the control. Significant changes were also observed for DHA (C22:6 n3) in all treatments. This fatty acid tended to rise in D1 and diminish at higher doses.

\subsection{Estimated activity of fatty acid desaturases and elongases}

Desaturase and elongase activities were determined in the muscle of $H$. forskali exposed to gradual doses of mercury (Table 2). The obtained results showed that D9D (C18:1n9/C18:0), D5D (C20:4n6/C20:3n-6) and Elongase 6 (C18:0/C16:0) activities decreased significantly at the lower doses (40 and $80 \mu \mathrm{g} \cdot \mathrm{L}^{-1}$ ) but remained unaffected at the highest dose (Table 2). The activity of the D6D: $\Delta 6$ desaturase (C22:6n-3/C20:5n-3) was significantly influenced by $\mathrm{Hg}$ exposure, expressing much higher values at D1 when compared to the control group.

\subsection{Principal component analysis}

The PCA carried out on the fatty acid composition data matrix produced a two-dimensional pattern which explained $77.7 \%$ of total variance (Figure 2). Those two components explained 56.7 (PC1) and $21.0 \%$ (PC2) of the total variance. The PCA plot showed a considerable distinction between control and treated groups along the PC2 axis. In addition, we noticed that the group exposed to the lowest dose (D1) was separated from all other groups along the $\mathrm{PC} 1$ axis. The most highly-sensitive fatty acids were C18:4n. 3 and $\mathrm{C} 14: 1$ for the PC1 axis and C17:0 and C20:0 for the PC2 axis.

\section{DISCUSSION}

Heavy metals such as mercury are potential stressors that exert toxic effects through redox cycling which results in the uncontrolled production of ROS and a failure in antioxidant defense systems (Lushchak, 2011). In the current study, an over production of ROS was confirmed by the increase in the $\mathrm{H}_{2} \mathrm{O}_{2}$ level in all $\mathrm{Hg}$-treated groups. Our results are consistent with several studies which reported a close correlation between the generation of intracellular ROS and the toxicity exerted by the inorganic $\mathrm{Hg}$ in several marine organisms (Verlecar et al., 2008; Wang et al., 2016). In this context, Patrick (2002) reported that exposure to $\mathrm{Hg}$ promotes the synthesis of $\mathrm{H}_{2} \mathrm{O}_{2}$, which could be converted into a reactive hydroxyl radical and lipid peroxidation (LPO) products in mitochondrial membranes. Furthermore, $\mathrm{Hg}$ ions are able to increase the action potential in the inner membrane of the mitochondria which regulates $\mathrm{HO}^{-}, \mathrm{O}_{2}^{-}$and $\mathrm{H}_{2} \mathrm{O}_{2}$, and negatively 
TABLE 2. Estimated fatty acid desaturase and elongase activities of Holothuria forskali muscle of control and $\mathrm{HgCl}_{2}$-treated groups (D1(40 $\left.\mu \mathrm{g} \cdot \mathrm{L}^{-1}\right), \mathrm{D} 2\left(80 \mu \mathrm{g} \cdot \mathrm{L}^{-1}\right)$ and $\left.\mathrm{D} 3\left(160 \mu \mathrm{g} \cdot \mathrm{L}^{-1}\right)\right)$ for 4 days.

\begin{tabular}{|c|c|c|c|c|}
\hline $\begin{array}{l}\text { Treatments and } \\
\text { parameters }\end{array}$ & Control & D1 & D2 & D3 \\
\hline D9D(18:1n9/18:0) & $0.4 \pm 0.07$ & $0.18 \pm 0.14^{* *}$ & $0.30 \pm 0.03^{*}$ & $0.45 \pm 0.02$ \\
\hline D5D(20:4n6/20:3n6) & $0.79 \pm 0.05$ & $0.27 \pm 0.049^{* *}$ & $0.38 \pm 0.05^{* *}$ & $1.183 \pm 0.2^{* *}$ \\
\hline $\mathrm{D} 6 \mathrm{D}(22: 6 \mathrm{n} 3 / 20: 5 \mathrm{n} 3)$ & $1.15 \pm 0.01$ & $5.4 \pm 1.04^{* * *}$ & $1.39 \pm 0.06$ & $0.87 \pm 0.08^{*}$ \\
\hline Elovl6(18:0/C16:0) & $1.23 .16 \pm 0.04$ & $0.7 \pm 0.08^{* *}$ & $1.14 \pm 0.03$ & $0.62 \pm 0.08^{*}$ \\
\hline
\end{tabular}

Results are given in means \pm standard deviation of nine replicates in each group.

D1, D2, and D3 vs control: *p $<0.05 ; * * \mathrm{p}<0.01 ; * * * \mathrm{p}<0.001$ (using Tukey's test)

D9D: $\Delta 9$-desaturase (stearoyl-CoA-desaturase $=18: \ln 9 / 18: 0$ );

D5D: $\Delta 5$-desaturase $(20: 4 \mathrm{n} 6 / 20: 3 \mathrm{n}-6)$;

D6D: $\Delta 6$-desaturase (22:6n-3/20:5n-3);

Elovl 6: Elongase 2 (18:0/C16:0).

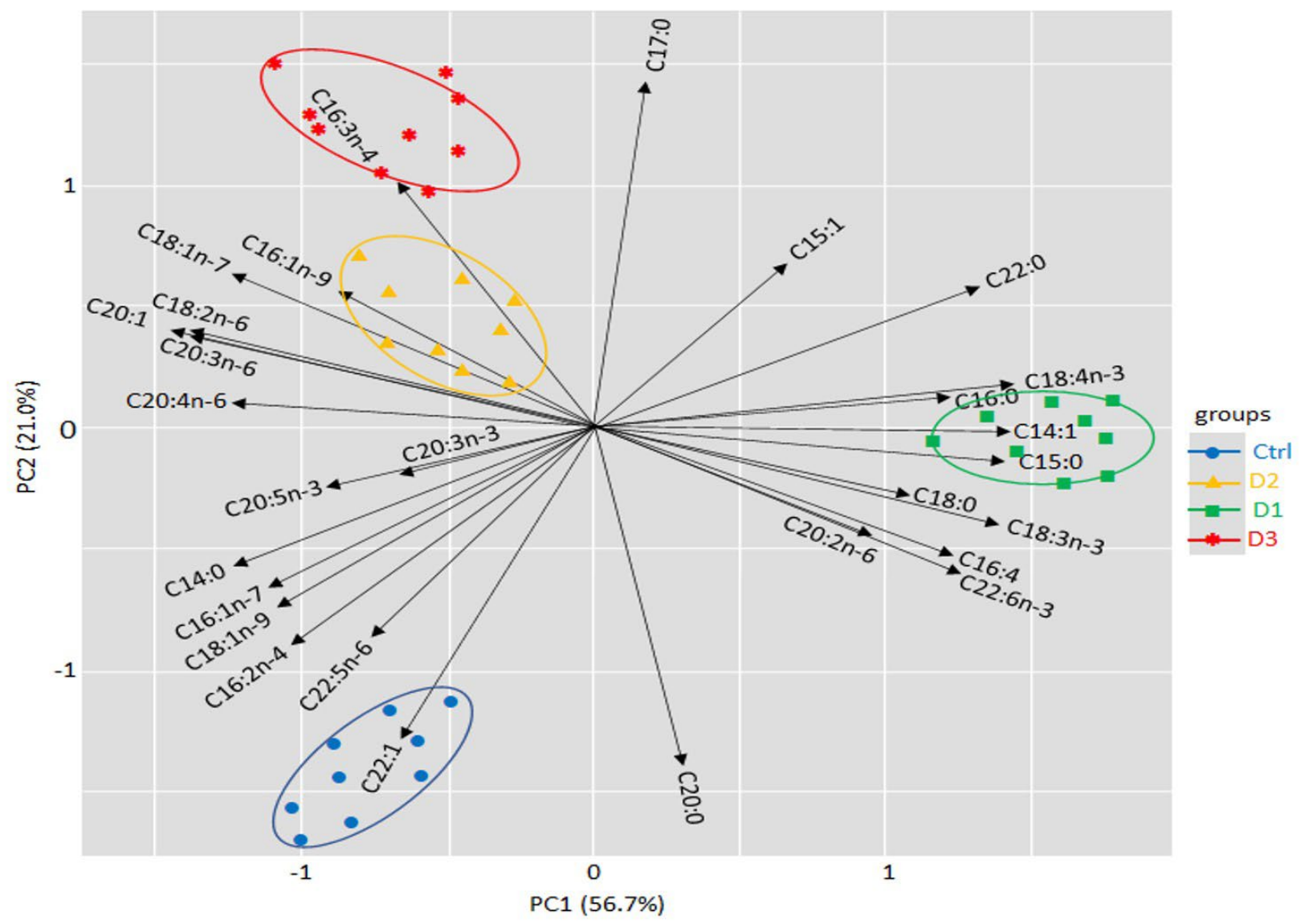

FIGURE 2. Principal component analysis (PCA) represented by two factors ( $\mathrm{F} 1=56.7 \%$ and $\mathrm{F} 2=21.0 \%$ ) and produced by fatty acid composition of Holothuria forskali muscle of control and $\mathrm{HgCl}_{2}$-treated groups (D1 $\left(40 \mu \mathrm{g} \cdot \mathrm{L}^{-1}\right), \mathrm{D} 2\left(80 \mu \mathrm{g} \cdot \mathrm{L}^{-1}\right)$ and D3 $\left.\left(160 \mu \mathrm{g} \cdot \mathrm{L}^{-1}\right)\right)$ for 4 days. 
adjusts the defense enzymes SOD, CAT, GPx, as well as GSH (Flores et al., 2019).

Besides biomarker analysis, the determination of the fatty acid composition has proven to be a good indicator of stress and ecosystem health, due to their high sensitivity to stress factors and environmental changes (Gonçalves et al., 2016). Indeed, changes in lipid metabolism are known to be a common biochemical response to pollutant exposure and accumulation in marine organisms (Dailianis et al., 2011). Our results showed significant changes in the FA composition of treated sea cucumbers indicating an evident harmful impact of $\mathrm{Hg}$ on lipid metabolism. Thereby, after exposure to $\mathrm{Hg}$, the FA profile of sea cucumber showed directional tendency anchored by an increase in SFAs, and the decrease in MUFAs and PUFAs levels. The observed changes are thought to be a compensatory process to defend the integrity of biological membranes and reduce cytotoxicity (Signa et al., 2015). It should also be noted that the most prominent changes in the FA composition of the Hg-treated $H$. forskali were mostly recorded at the lowest tested dose as confirmed further by the PCA analysis. Such findings can be attributed to a hormeosis response and suggest that low $\mathrm{Hg}$ dose response may be considered as a manifestation of the plasticity of biological systems. In fact, hormeosis, which is a dose-response phenomenon characterized by a low-dose stimulation and a highdose inhibition, was observed for Algae exposed to silver ions and nanoparticles (Tayemeh et al., 2020). The increased proportions of SFA mostly resulted from the increment in palmitic acid (C16:0) and may reflect an inflammation response to $\mathrm{Hg}$ intoxication. Indeed, the last cited FA is particularly known as a potent agent involved in the activation of proinflammatory signaling pathways (Ma et al., 2018). Another interesting finding recorded in the current study is the decrease in the MUFA group mainly due to the diminution of the oleic acid (C18:1n-9, OA) level. The latter is a nonessential FA which derives from the desaturation of stearic acid (C18:0) by the stearoyl-CoA desaturase (Scd). The recorded decline in the OA level is probably due to the inhibition of the $\Delta 9$-desaturase activity by $\mathrm{Hg}$ ions as reflected by the product-to-precursor ratio used in the current study. Furthermore, OA was probably used for energy production through $\beta$-oxidation and/ or in modulation of membrane fluidity (Funari et al.,
2003) and/or in detoxification related mechanisms as suggested by Ruiz-Gutiérrez et al., (1999). Also worthy of note, a significant depletion of the n- 6 group and particularly ARA (C20:4n-6) and its precursor LA (C18:2n-6), which are presumably required for activation of eicosanoid synthesis through the arachidonic cascade. In fact, ARA is largely reported in the literature to be an important mediator involved in inflammation, immune response, and adaptation to stress through eicosanoid pathways (Calder, 2015). Likewise, we note the expenditure of EPA, another precursor to eicosanoids, which may reflect a compensatory mechanism to maintain membrane fluidity and to promote the adaptive response of the organism to stress (Delaporte et al., 2006). Another PUFA, docosahexaenoic acid (DHA), which is a main component of membrane phospholipids, was found to increase in Hg-treated animals. Such findings might reflect the ability of $H$. forskali to cope with $\mathrm{Hg}$ injuries through the induction of $\Delta 6$ desaturase activity as reflected by the enhanced $22: 6 n-3 / 22: 5 n-3$ ratio. Indeed, it has been proven that the DHA may act as an antioxidant to reduce lipid peroxidation (Mayurasakorn et al., 2016). Furthermore, Vanse et al. (2002) reported that DHA could be involved in modulating the inflammatory response and regulating membrane homeoviscous to protect the cell from oxidative disruption caused by $\mathrm{Hg}$ intrusion. Similar pictures were observed for other marine organisms following exposure to metals and organic pollutants (Telahigue et al., 2019; Silva et al., 2017).

To further explore the impact of $\mathrm{Hg}$ on lipid metabolism, LOOH levels, primary breakdown products of long-chain fatty acid peroxidation, were determined. The increased LOOH levels recorded in all $\mathrm{Hg}$-treated groups clearly reflected the dysfunction of the mitochondrial respiratory chain. Indeed, being rich in polyunsaturated fatty acids (PUFA) as other marine organisms (Liu et al., 2017), sea cucumber seemed to be vulnerable to lipid peroxidation. The continued oxidation of fatty acid, and the fragmentation of peroxides to produce aldehydes may eventually lead to losses in membrane integrity by alteration of its fluidity.

\section{CONCLUSIONS}

In the current study, the acute exposure to $\mathrm{Hg}$ promoted a state of oxidative stress as denoted by 
increased hydrogen peroxide and lipid hydroperoxide levels. The changes in the FA profiles of treated sea cucumber clearly indicated an evident toxic effect of $\mathrm{Hg}$ on the longitudinal muscle. The palette of acids, including SFA, MUFA and PUFA, determined in the muscle tissue, can be used in ecotoxicological research as an efficient test of the effect of mercury exposure. Furthermore, the prominent effects observed at the lowest dose, which is probably due to a hormeosis response, must be interpreted with caution since no information is available concerning the mechanistic difference between the toxicity and inhibitory effects of mercury to fatty acid pathways in holothurians. Lastly, our findings extend the understanding of the adaptive mechanisms of sea cucumbers and the usefulness of the FA analysis as a biomarker for $\mathrm{Hg}$ contamination.

\section{ACKNOWLEDGEMENTS}

The authors are indebted to the editor and the anonymous reviewers for their acceptance to review this work and their valuable comments and suggestions for improving the quality of the manuscript.

\section{REFERENCES}

Balshaw S, Edwards JW, Ross KE, Daughtry BJ. 2008. Mercury distribution in the muscular tissue of farmed southern bluefin tuna (Thunnus maccoyii) is inversely related to the lipid content of tissues. Food Chem. 111, 616- 621. https://doi. org/10.1016/j.foodchem.2008.04.041

Bhamre PR, Thorat SP, Desai AE. 2010. Evaluation of acute toxicity of mercury, cadmium and zinc to a freshwater mussel Lamellidens consobrinus. Our Nat. 8, 180-184.

Bordbar S, Anwar F, Saari N. 2011. High-value components and bioactives from sea cucumbers for functional foods-A Review. Mar. Drugs 9 (10), 1761-1805. https://doi.org/10.3390/md9101761

Calder PC. 2015. Marine omega-3 fatty acids and inflammatory processes: effects, mechanisms and clinical relevance. Biochim. Biophys. Acta Mol. Cell Biol Lipids 1851, 469-484. https://doi. org/10.1016/j.bbalip.2014.08.010

Cecchi G, Basini S, Castano C. 1985. Méthanolyse rapide des huiles en solvant. Rev. Franc. Corps Gras 4, 63-164.
Da Costa F, Robert R, Quéré C, Wikfors GH, Soudant P. 2015. Essential fatty acid assimilation and synthesis in larvae of the bivalve Crassostrea gigas. Lipids 50 (5), 503-511. https://doi.org/10.1007/ s11745-015-4006-Z

Dailianis S. 2011. Environnemental impact of anthropogenic activities: the use of mussels as a reliable tool for monitoring marine pollution. In: McGevin, L.E. (Ed.), Mussels: Anatomy. Habitat and Environmental Impact. Nova Science Publishers. Inc. pp. 1-30.

Dindia LA, Faught EL, Leonenko Z, Thomas RH, Vijayan MM. 2013. Rapid cortisol signaling in response to acute stress involves changes in plasma membrane order in rainbow trout liver. Am. $J$. Physiol. Endoc. M. 304, E1157-E1166

Delaporte M, Soudant P, Moal J, Kraffe E, Marty Y, Samain J.F .2005. Incorporation and modification of dietary fatty acids in gill polar lipids by two bivalve species Crassostrea gigas and Ruditapes philippinarum. Comp. Biochem. Phys. A 140, 460-470.

Folch J, Lees M, Sloane-Stanley GA. 1957. A simple method for the isolation and purification of total lipids from animal tissues. J. Biol. Chem. 226 (1) 497-509.

Flores JS, Torres-Jasso JH, Rojas-Bravo D, Reyna-Villela ZM, Erandis D, Torres-Sánchez ED. 2019. Effects of Mercury, Lead, Arsenic and Zinc to Human Renal Oxidative Stress and Functions: A Review. J. Heavy Met. Toxicity Dis. 4, 1-2. https://doi.org/10.21767/2473-6457.10027

Filimonova V, Gonçalves F, Marques JC, De Troch M, Gonçalves ANN. 2016. Fatty acid profiling as bioindicator of chemical stress in marine organisms: A review. Ecol. Indic. 67, 657-672. https:// doi.org/10.1016/j.ecolind.2016.03.044

Ferain A, Bonnineau C, Neefs I, Das K, Larondelle Y, Rees JF, Debier C, Lemaire B. 2018. Transcriptional effects of phospholipid fatty acid profile on rainbow trout liver cells exposed to methylmercury. Aquat. Toxicol. 199, 174-187.

Funari SS, Barceló F, Escribá PV. 2003. Effects of oleic acid and its congeners, elaidic and stearic acids, on the structural properties of phosphatidylethanolamine membranes. J. Lipid R. 44, 567575. https://doi.org/10.1194/jlr.M200356-JLR200

Gonçalves A, Mesquita A, Verdelhos T, Coutinho J, Marques J, Gonçalves F. 2016. Fatty acids pro- 
files as indicator of stress induced by of a common herbicide on two marine bivalves species: Cerastoderma edule (Linnaeus, 1758) and Scrobicularia plana (da Costa, 1778). Ecol. Indic. 63, 209-218. https://doi.org/10.1016/j.ecolind.2015. 12.006

Holman TR. 1954. Autoxidation of fats and related substances. In Progress in the Chemistry of Fats and Other Lipids. Academic Press, New York. 2, 491-514.

Jiang ZY, Hunt JV, Wolf SP. 1992. Detection of lipid hydroperoxides using Fox method. Anal. Biochem. 202, 384-389.

Kotronen A, Seppanen-Laakso T, Westerbacka J, Arola J, Ruskeepaa AL, Yki-Jarvinen H, Oresic M. 2011. Comparison of lipid and fatty acid composition of the liver, subcutaneous and intra-abdominal adipose tissue, and serum. Obesity 18, 937-944

Lushchak VI. 2011. Environmentally induced oxidative stress in aquatic animals. Aquatic Toxicol. 719 (101), 13-30.

Liu X, Wang L, Feng Z, Song X, Zhu X. 2017b. Molecular cloning and functional characterization of the fatty acid delta 6 desaturase (FAD6) gene in the sea cucumber Apostichopus japonicus. Aquac. Res. 48, 4991-5003.

Los DA, Murata N. 2004. Membrane fluidity and its roles in the perception of environmental signals. Biochim. Biophys. Acta 1666, 142-157. https:// doi.org/10.1016/j.bbamem.2004.08.002

Munro D, Banh S, Sotiri, Tamanna N, Treberg J. 2016. The thioredoxin and glutathione $\square$ dependent $\mathrm{H}_{2} \mathrm{O}_{2}$ consumption pathways in muscle mitochondria: Involvement in $\mathrm{H}_{2} \mathrm{O}_{2}$ metabolism and consequence to $\mathrm{H}_{2} \mathrm{O}_{2}$ efflux assays. Free Radic. Biol. Med. 96, 334-346. https://doi.org/10.1016/j. free radbiomed.2016.04.014

Ma XZ, Pang ZD, Wang JH, Song Z, Zhao LM, Du XJ, Deng XL. 2018. The role and mechanism of $\mathrm{K}_{\mathrm{Ca}} 3.1$ channels in human monocyte migration induced by palmitic acid. Exp. Cell Res. 369, 208217. https://doi.org/10.1016/j.yexcr.2018.05.020

Mayurasakorn K, Niatsetskaya ZV, Sosunov SA, Williams JJ, Zirpoli H, Vlasakov I, Ten VS. 2016. DHA but not EPA emulsions preserve neurological and mitochondrial function after brain hypoxia-ischemia in neonatal mice. PLOS One 11. https://doi.org/10.1371/journal.pone.0160870
Navarro PG, García-Sanz S, Tuya F. 2014. Contrasting displacement of the sea cucumber Holothuria arguinensis between adjacent nearshore habitats. J. Exp. Mar. Biol. Ecol. 453, 123-130. https://doi. org/10.1016/j.jembe.2014.01.008

Neves M, Castro BB, Vidal T, Vieira R, Marques JC, Coutinho JAP, Gonçalves F. 2015. Biochemical and populational responses of an aquatic bioindicator species, Daphnia longispina, to a commercial formulation of an herbicide (primextraç gold TZ) and its active ingredient (S-metolachlor). Ecol. Indic. 53, 220-230. https://doi. org/10.1016/j.ecolind.2015.01.031

Oliveira P, Lopes-Lima M, Machado J, Guilhermino L. 2015. Comparative sensitivity of European native (Anodonta anatina) and exotic (Corbicula fluminea) bivalves to mercury. Estuar. Coast. ShelfSci. 167, 191-198. https://doi.org/10.1016/j. ecss.2015.06.014

Ou P, Wolff SP. 1996. A discontinuous method for catalase determination at near physiological concentrations of $\mathrm{H}_{2} \mathrm{O}_{2}$ and its application to the study of $\mathrm{H}_{2} \mathrm{O}_{2}$ fluxes within cells. J. Biochem. Biophys. Meth. 31 (1-2), 59-67

Patrick L. 2002. Mercury toxicity mercury toxicity and antioxidants: Part 1: role of glutathione and alpha-lipoic acid in the treatment of mercury toxicity. Altern. Med. Rev. 7 (6), 456-471.

Rabeh, Telahigue K, Bejaoui S, Hajji T, Nechi S, Chelbi E, EL Cafsi M, Soudani N. 2019. Effects of mercury graded doses on redox status, metallothione in levels and genotoxicity in the intestine of sea cucumber Holothuria forskali. Chem. Ecol. 35 (3), 204-218. https://doi.org/10.1080/02 757540.2018 .1546292

Rabei A, Hichami A, Beldi H, Bellenger S, Khan NA, Soltani N. 2018. Fatty acid composition, enzyme activities and metallothioneins in Donax trunculus (Mollusca, Bivalvia) from polluted and reference sites in the Gulf of Annaba (Algeria): pattern of recovery during transplantation. Environ. Pollut. 237, 900-907. https://doi.org/10.1016/j. envpol.2018.01.041

Ruiz-Gutierrez V, Muriana FJ, Guerrero A, Cert AM, Villar J. 1996. Plasma lipids, erythrocyte membrane lipids and blood pressure of hypertensive women after ingestion of dietary oleic acid from two different sources. J. Hypertens 14, $1483-$ 1490. 
Ruiz F, González-Regalado ML, Muñoz JM, Abad M, Toscano A, Prudencio MI, Dias MI. 2014. Distribution of heavy metals and pollution pathways in a shallow marine shelf: assessment for a future management. J. Environ. Sci. Technol. 11, 1249. https://doi.org/10.1007/s13762-014-0576-1

Silva CO, Simões T, Novais SC, Pimparel I, Granada L, Soares AM, Barata C, Lemos MF. 2017. Fatty acid profile of the sea snail Gibbula umbilicalis as a biomarker for coastal metal pollution. Sci. Total Environ. 15 (586), 542-550. https://doi. org/10.1016/j.scitotenv.2017.02.015

Signa G, Di Leonardo R, Vaccaro A, Tramati CD, Mazzola A, Vizzini S. 2015. Lipid and fatty acid biomarkers as proxies for environmental contamination in caged mussels Mytilus galloprovincialis. Ecol. Indic. 57, 384-394.

Sicuro B, Levine J. 2011. Sea cucumber in the Mediterranean: a potential species for aquaculture in the Mediterranean. Rev. Fish. Sci. 19, 299-304. https://doi.org/10.1080/10641262.2011.598249

Tayemeh MB, Esmailbeigi M, Shirdel I, Joo HS, Johari SA, Banan A, Nourani H, Mashhadi H, Jami MJ, Tabarrok M. 2020. Perturbation of fatty acid composition, pigments, and growth indices of Chlorella vulgaris in response to silver ions and nanoparticles: A new holistic understanding of hidden ecotoxicological aspect of pollutants. Chemosphere 238, 124576. https://doi. org/10.1016/j.chemosphere.2019.124576

Thyrring J, Juhl BK, Holmstrup M, Blicher ME, Sejr M. 2015. Does acute lead $(\mathrm{Pb})$ contamination influence membrane fatty acid composition and freeze tolerance in intertidal blue mussels in arctic Greenland? Ecotel. 24, 2036-2042. https:// doi.org/10.1007/s10646-015-1539-0

Turk Culha S, Dereli H, Karaduman FR, Culha M. 2016. Assessment of trace metal contamination in the sea cucumber (Holothuria tubulosa) and sediments from the Dardanelles Strait (Turkey). Environ. Sci. Pollut. R. 23 (12), 11584-11597.

Telahigue K, Rabeh I, Bejaoui S, Hajji T, Nechi S, Chelbi E, El Cafsi M, Soudani N. 2018. Mercury disrupts redox status, up-regulates metallothionein and induces genotoxicity in respiratory tree of sea cucumber (Holothuria forskali). Drug. Chem. Toxicol. 43 (3), 287-297. https://doi.org/1 0.1080/01480545.2018.1524475

Telahigue K, Rabeh I, Hajji T, Trabelsi W, Bejaoui S, Chouba L, El Cafsi M, Soudani N. 2019. Effects of acute mercury exposure on fatty acid composition and oxidative stress biomarkers in Holothuria forskali body wall. Ecotox. Environ. Safe. 169, 516-522. https://doi.org/10.1016/j. ecoenv.2018.11.051

Uttara B, Singh AV, Zamboni P, Mahajan RT. 2009. Oxidative stress and neurodegenerative diseases: a review of upstream and downstream antioxidant therapeutic options. Curr. Neuropharmacol. 7, 65-74. https://doi. org/10.2174/157015909787602823

Verlecar XN, Jena KB, Chainy GBN. 2008. Modulation of antioxidant defences in digestive gland of Pernaviridis (L.), on mercury exposures. Chemosphere 71, 1977-1985. https://doi.org/10.1016/j. Chemosphere.2007.12.014

Vigh L, Nakamoto H, Landry J, Gomez-Muñoz A, Harwood DJL, Horvath I. 2007. Membrane regulation of the stress response from prokaryotic models to mammalian cells. Ann. N. Y. Acad. Sci. 1113, 40-51. https://doi.org/10.1196/annals. 1391.027

Wang P, Wang R, Wang C, Qian J, Hou J. 2016. Exposure-dose-response relationships of the freshwater bivalve Corbicula fluminea to inorganic mercury in sediments. J. Comput. Theor. Nanosci. 13, 5714-5723. https://doi.org/10.1166/jctn. 2016.5476 